This is an electronic reprint of the original article. This reprint may differ from the original in pagination and typographic detail.

\author{
Author(s): Hossain, Md. Kamal; Schachner, Jörg A.; Haukka, Matti; Lehtonen, Ari; Mösch-Zanetti, \\ Nadia C.; Nordlander, Ebbe
}

Title: $\quad$ Dioxidomolybdenum(VI) and -tungsten(VI) Complexes with Tripodal Amino Bisphenolate Ligands as Epoxidation and Oxo-transfer Catalysts

Year: $\quad 2017$

Version:

Please cite the original version:

Hossain, M. K., Schachner, J. A., Haukka, M., Lehtonen, A., Mösch-Zanetti, N. C., \& Nordlander, E. (2017). Dioxidomolybdenum(VI) and -tungsten(VI) Complexes with Tripodal Amino Bisphenolate Ligands as Epoxidation and Oxo-transfer Catalysts. Polyhedron, 134, 275-281. https://doi.org/10.1016/j.poly.2017.04.036

All material supplied via JYX is protected by copyright and other intellectual property rights, and duplication or sale of all or part of any of the repository collections is not permitted, except that material may be duplicated by you for your research use or educational purposes in electronic or print form. You must obtain permission for any other use. Electronic or print copies may not be offered, whether for sale or otherwise to anyone who is not an authorised user. 


\section{Accepted Manuscript}

Dioxidomolybdenum(VI) and -tungsten(VI) Complexes with Tripodal Amino Bisphenolate Ligands as Epoxidation and Oxo-transfer Catalysts

Md. Kamal Hossain, Jörg A. Schachner, Matti Haukka, Ari Lehtonen, Nadia C. Mösch-Zanetti, Ebbe Nordlander

PII: S0277-5387(17)30327-3

DOI: http://dx.doi.org/10.1016/j.poly.2017.04.036

Reference: POLY 12618

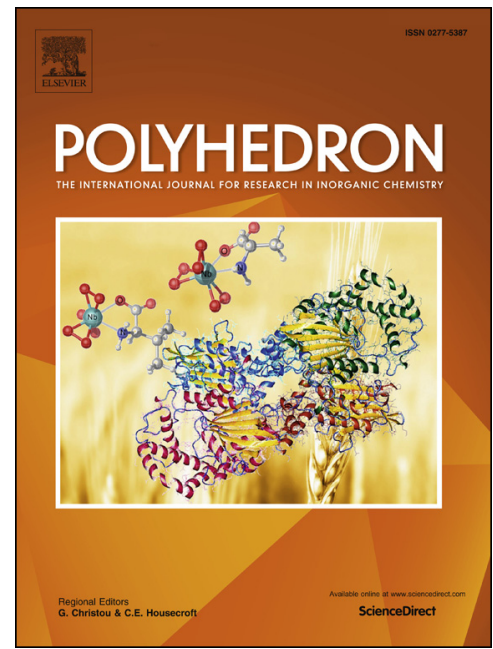

To appear in:

Polyhedron

Received Date:

22 December 2016

Accepted Date:

27 April 2017

Please cite this article as: d.K. Hossain, J.A. Schachner, M. Haukka, A. Lehtonen, N.C. Mösch-Zanetti, E. Nordlander, Dioxidomolybdenum(VI) and -tungsten(VI) Complexes with Tripodal Amino Bisphenolate Ligands as Epoxidation and Oxo-transfer Catalysts, Polyhedron (2017), doi: http://dx.doi.org/10.1016/j.poly.2017.04.036

This is a PDF file of an unedited manuscript that has been accepted for publication. As a service to our customers we are providing this early version of the manuscript. The manuscript will undergo copyediting, typesetting, and review of the resulting proof before it is published in its final form. Please note that during the production process errors may be discovered which could affect the content, and all legal disclaimers that apply to the journal pertain. 


\title{
Dioxidomolybdenum(VI) and -tungsten(VI) Complexes with Tripodal Amino Bisphenolate Ligands as Epoxidation and Oxo-transfer Catalysts
}

Md. Kamal Hossain, ${ }^{a}$ Jörg A. Schachner, ${ }^{b}$ Matti Haukka, ${ }^{c}$ Ari Lehtonen, ${ }^{d} *$ Nadia C. Mösch-Zanetti, ${ }^{\mathrm{b}, *}$ Ebbe Nordlander ${ }^{\mathrm{a}, *}$

a. Chemical Physics, Department of Chemistry, Lund University, P. O. Box 124, SE22100 Lund, Sweden

b. Institute of Chemistry, Department of Inorganic Chemistry, University of Graz Schubertstraße 1, 8010 Graz, Austria

c. Department of Chemistry, P.O. Box 35, University of Jyväskylä, FI-40014 Jyväskylä, Finland

d. Inorganic Materials Chemistry Research Group, Laboratory of Materials Chemistry and Chemical Analysis, Department of Chemistry, University of Turku, 20014, Turku, Finland

Corresponding author

E-mail address: Ebbe.Nordlander@chemphys.lu.se (E. Nordlander)

\begin{abstract}
The molybdenum(VI) and tungsten(VI) complexes $\left[\mathrm{MO}_{2}(\mathbf{L})\right]\left(\mathrm{M}=\mathrm{Mo}(\mathbf{1}), \mathrm{W}(\mathbf{2}), \mathbf{H}_{\mathbf{2}} \mathbf{L}=\right.$ bis(2-hydroxy-3,5-di-tert-butybenzyl)morpholinylethylamine)) were synthesized and the complexes were used to catalyse oxotransfer reactions, viz. sulfoxidation, epoxidation and benzoin oxidation. For comparison, the same reactions were catalysed using the known complexes $\left[\mathrm{MO}_{2}\left(\mathbf{L}^{\prime}\right)\right] \quad\left(\mathrm{M}=\mathrm{Mo} \quad(\mathbf{3}), \quad \mathrm{W} \quad(\mathbf{4}), \quad \mathbf{H}_{2} \mathbf{L}^{\prime}=\right.$ bis(2-hydroxy-3,5-di-tertbutybenzyl)ethanolamine) and $\left[\mathrm{MO}_{2}\left(\mathbf{L}^{\prime \prime}\right)\right]\left(\mathbf{M}=\mathrm{Mo}(\mathbf{5}), \mathrm{W}(\mathbf{6}), \mathbf{H}_{2} \mathbf{L}^{\prime \prime}=\right.$ bis(2-hydroxy-3,5-ditert-butybenzyl)diethyleneglycolamine). The oxo atom transfer activity between DMSO and benzoin at $120{ }^{\circ} \mathrm{C}$ was identical for all studied catalysts. Reasonable catalytic activity was observed for sulfoxidation by the molybdenum complexes, but all tungsten complexes were found to be inactive. Similarly, the molybdenum complex 1 exhibited relatively good epoxidation activity, while the corresponding tungsten complex $\mathbf{2}$ catalysed only the epoxidation of cis-cyclooctene with low activity.
\end{abstract}

Keywords: Molybdenum $\bullet$ Tungsten $\bullet$ Sulfoxidation $\bullet$ Epoxidation $\bullet$ Oxygen Atom transfer 


\section{Introduction}

Electronic and steric properties of ligands are routinely used to tune the reactivity of metal species. For example, to obtain robust high-valent metal complexes that are stable under catalytic conditions, a number of bulky anionic ligands with hard oxygen donor atoms have been used. Various phenolate ligands, in particular, have shown great promise towards this end [1-10]. Amino bisphenols with different side-arm donors are potentially tetradentate ligands that can form stable complexes with all transition metals [11]. Such ligands can occupy four coordination sites around the metal centre and thus keep the coordination number sufficiently high to prevent the undesirable dimerization of reactive intermediates in the catalytic reaction cycles. On the other hand, if the side-arm donor is sufficiently labile, it may dissociate, if necessary, during the catalytic reaction. Thus, the nature of the side-arm donor may play a crucial role for the stability and activity of the catalytically active species. A number of amino phenolate complexes with transition metals have been studied as catalysts for oxidation reactions, as well as model compounds for the active sites of metal enzymes. [12-23].

We are interested in the development of new molybdenum(VI) and tungsten(VI) based catalysts for several biologically as well as industrially important catalytic oxidation reactions, for example such oxygen atom transfer (OAT) processes as epoxidation and sulfoxidation [24-26]. We have previously reported the catalytic potential of dioxidomolybdenum and dioxidotungsten complexes bearing tripodal tetradentate amino bisphenolate ligands with either a hydroxyethylene substituent $(\mathrm{R}=\mathrm{H})\left(\mathbf{L}^{\prime}\right)$ or a hydroxyglycolene substituent $\left(\mathrm{R}=\left(\mathrm{CH}_{2}\right)_{2} \mathrm{OH}\right)\left(\mathrm{L}^{\prime \prime}\right)$ (complexes 3-6 in Figure 1) [10a]. These catalysts exhibit high activity in the epoxidation of cis-cyclooctene with either tert-butyl hydroperoxide $(t \mathrm{BuOOH})$ or hydrogen peroxide $\left(\mathrm{H}_{2} \mathrm{O}_{2}\right)$ as ultimate oxidants [10a]. In this study, we have used molybdenum and tungsten complexes of a morpholine-substituted amino bisphenolate ligand (L) (complexes $\mathbf{1}$ and $\mathbf{2}$ in Figure 1). The dangling oxygen atom in the morpholine motif may make the ligand more prone to accept $\mathrm{H}$-bonds from hydroperoxide oxidants and thus bring oxidant molecules closer to the reaction centre, and may thus render the complexes more potent for the catalysis. Complexes $\mathbf{1}$ and $\mathbf{2}$ were studied as catalysts for the epoxidation of olefins while all compounds 1-6 were tested as catalysts in sulfoxidation and benzoin oxidation.

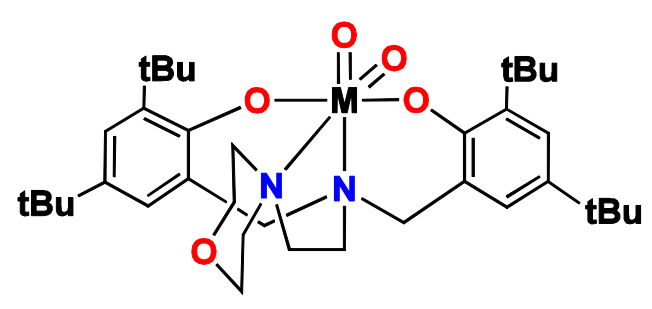

$M=M o, 1$ and $M=W, 2$

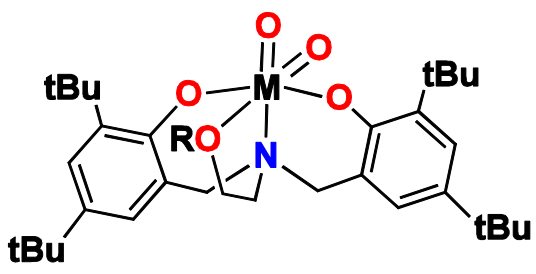

$$
\begin{aligned}
& M=M o, R=H, 3 \\
& M=W, R=H, 4 \\
& M=M o, R=\left(C_{2}\right)_{2} \mathrm{OH}, 5 \\
& M=W, R=\left(\mathrm{CH}_{2}\right)_{2} \mathrm{OH}, 6
\end{aligned}
$$

Figure 1. Molybdenum and tungsten complexes used in this study. 


\section{Results and discussion}

\subsection{Syntheses}

The synthesis of the tripodal amino bisphenol proligand $\mathbf{H}_{2} \mathbf{L}$ has been reported earlier [27]. In this study, it was prepared by a solvent-free Mannich condensation reaction applying a published procedure [28]. Recrystallization from hexane gave crystals suitable for X-ray crystallographic analyses. The reaction of $\mathbf{H}_{2} \mathbf{L}$ with $\left[\mathrm{MoO}_{2}(\mathrm{acac})_{2}\right]$ in acetonitrile solution at room temperature led to the crystallization of the acetonitrile adduct $\left[\mathrm{MoO}_{2}(\mathbf{L})\right] \cdot \mathrm{MeCN}$ $(\mathbf{1} \cdot \mathrm{MeCN})$ in a yield of $69 \%$. Complex $\mathbf{1}$ may alternatively be prepared by the reaction of $\mathbf{H}_{2} \mathbf{L}$ with other starting materials, such as $\left[\mathrm{MoO}_{2} \mathrm{Cl}_{2}\right]$, in refluxing toluene followed by recrystallization from hot acetonitrile. The molecular structure of the complex was found to be identical to the methanol adduct published recently [27].

The tungsten complex 2 was prepared from $\left[\mathrm{W}(\mathrm{eg})_{3}\right]\left(\mathrm{eg}=\right.$ the glycolate dianion) and $\mathbf{H}_{2} \mathbf{L}$ in a $\mathrm{CHCl}_{3}-\mathrm{MeOH}$ mixture. The yellow reaction mixture was stirred at $70{ }^{\circ} \mathrm{C}$ for an hour to obtain $\mathbf{2} \cdot \mathrm{MeOH}$ as a white crystalline solid in $62 \%$ yield. The air- and moisture-stable compounds $\mathbf{1}$ and $\mathbf{2}$ are soluble in polar chlorinated and aromatic solvents but insoluble in non-polar solvents. Complex 2 was characterized by IR, ${ }^{1} \mathrm{H}$ and ${ }^{13} \mathrm{C}$ NMR spectroscopies. The coordination of the ligand to the metal centre was seen in the ${ }^{1} \mathrm{H}$ spectrum as a disappearance of the broad signal of the phenolic $\mathrm{OH}$ proton. In $\mathrm{CDCl}_{3}$ solutions, the ${ }^{1} \mathrm{H}$ spectrum shows sharp signals for aromatic protons as well as for the tert-butyl groups. The benzylic protons are seen as doublets, but the signals for all $\mathrm{CH}_{2}$ protons of the morpholine moiety are broad and overlapping. This indicates some dynamic process in solution, e.g. the equilibrium of different conformers of the ligand such as boat vs. chair conformation of the morpholine unit. The ${ }^{13} \mathrm{C}$ NMR spectrum of $\mathbf{2}$ shows 6 signals for aromatic carbons, 5 signals for $\mathrm{CH}_{2}$ carbons, 2 signals for $t \mathrm{Bu}$ central carbons and 2 signals for $t \mathrm{Bu}$ methyl groups, which is consistent with the expected $C_{s}$ symmetry of the complexes. This indicates that only the configurational isomer that involves trans orientation of the phenolate moieties of the ligand, and coordination of the basic amine moiety of the ligand trans to the oxido units is present ( $c f$. Figure 1).

For complex 2, stretching frequencies at 900 and $946 \mathrm{~cm}^{-1}$ were assigned as asymmetric and symmetric stretches, respectively [10a,24,29]. The ESI-MS spectrum showed a few major peaks; the molecular ion peaks for $[2+\mathrm{Na}]^{+}(\mathrm{m} / z=803),[2+\mathrm{H}]^{+}(\mathrm{m} / \mathrm{z}=781)$ and the found isotopic distributions were in a good agreement with the calculated spectra. The mass spectrum also shows a ligand molecular ion at $\left[\mathbf{H}_{2} \mathbf{L}+\mathrm{H}\right]^{+}(\mathrm{m} / z=567)$, as well as a peak envelope $(\mathrm{m} / \mathrm{z}=349)$ for a fragmented amino monophenolate moiety. 


\subsection{Crystal and molecular structures of $\mathrm{H}_{2} \mathrm{~L}$ and $\left[\mathrm{MO}_{2}(\mathrm{~L})\right](\mathrm{M}=\mathrm{Mo}(1), \mathrm{W}(2))$}

The proligand $\mathbf{H}_{2} \mathrm{~L}$ was crystallised from hexane and characterized by single-crystal X-ray crystallography as shown in Figure 2. Single crystals of $\mathbf{1}$ and $\mathbf{2}$ suitable for X-ray diffraction were isolated from the reaction mixtures. Complex 1 crystallizes with one molecule of $\mathrm{MeCN}$ in the asymmetric unit, while $\mathbf{2}$ crystallizes with a molecule of $\mathrm{MeOH}$. The molecular structures of $\mathbf{1}$ and $\mathbf{2}$ are shown in Figure 2, together with a capped-sticks representation of the superimposed structures of the two complexes. Relevant crystallographic data are summarized in Table 1, and selected bond lengths and angles are collated in Table 2. Both complexes are hexacoordinate with a nearly $C_{\mathrm{s}}$-symmetric distorted octahedral geometry, which is consistent with the observed NMR spectra (vide supra and supporting material). The amino bisphenolate ligand is coordinated to the cis $-\mathrm{MO}_{2}(\mathrm{M}=\mathrm{Mo}, \mathrm{W})$ moiety through two anionic phenolate oxygens and two neutral nitrogen donor atoms of the central amine and the morpholine

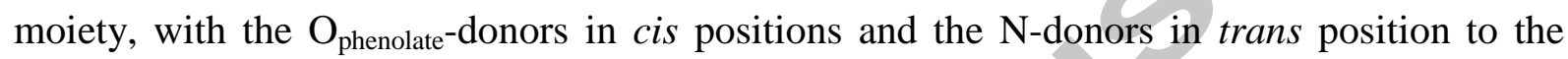
oxido ligands. The $\mathrm{O}_{\text {oxido }}-\mathrm{M}-\mathrm{N}$ angles deviate from $180^{\circ}$, presumably because of ligand constraints; for the central amine nitrogen of the ligand, the $\mathrm{O} 4-\mathrm{M}-\mathrm{N} 1$ angle is $157.5(8)^{\circ}$ for Mo and $156.3(2)^{\circ}$ for $\mathrm{W}$, and for the morpholine nitrogen the O3-M-N2 angle is $167.6(8)^{\circ}$ for Mo, $169.6(2)^{\circ}$ for $\mathrm{W}$. The positioning of the nitrogens trans to the oxido $\pi$-donor ligands results in long M-N bond distances, i.e. M-N1 distance is 2.3629(19) for $\mathbf{1}$ and 2.373(5) $\AA$ for 2 whereas the M-N2 distance is 2.445(2) for $\mathbf{1}$ and 2.455(5) $\AA$ for $\mathbf{2}$. Complex $\mathbf{2} \cdot \mathbf{M e O H}$ is essentially isostructural with the recently reported complex $\mathbf{1} \cdot \mathrm{MeOH}$ [27] (see Table 2). All $\mathrm{O}=\mathrm{M}=\mathrm{O}$ angles and $\mathrm{M}=\mathrm{O}$ distances resemble those found in other six-coordinate dioxidomolybdenum(VI) and -tungsten(VI) complexes [27,29-36]. The $\mathrm{M}-\mathrm{O}_{\text {phenolate }}$ angles are $125.82(17)$ and $120.28(16)^{\circ}$ for $\mathbf{1}$ and $122.7(4)$ and $127.8(4)^{\circ}$ for $\mathbf{2}$, whereas the corresponding $\mathrm{M}-\mathrm{O}_{\text {phenolate }}$ distances are 1.9393(19) and 1.9673(18) $\AA$ for $\mathbf{1}$ and 1.947(4) and 1.921(5) $\AA$ for 2, respectively. The larger angles are associated with shorter $\mathrm{M}-\mathrm{O}_{\text {phenolate }}$ bond distances and vice versa. The value of the M-O-C angle can in theory reflect the degree of $\pi$ donation from oxygen to the metal, but it has been found to be a flexible parameter and no clear correlation between the metal-phenolate angles and distances for d-block transition metal complexes has been established $[37,38]$. 


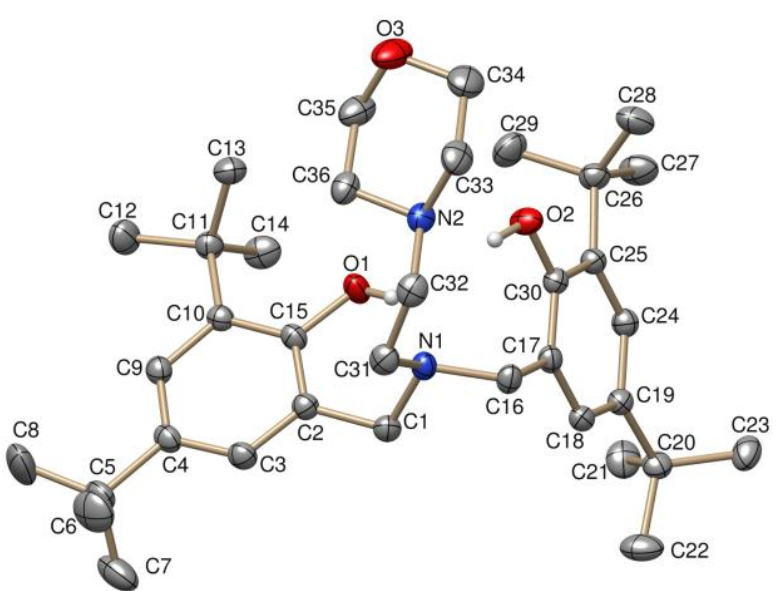

(a)

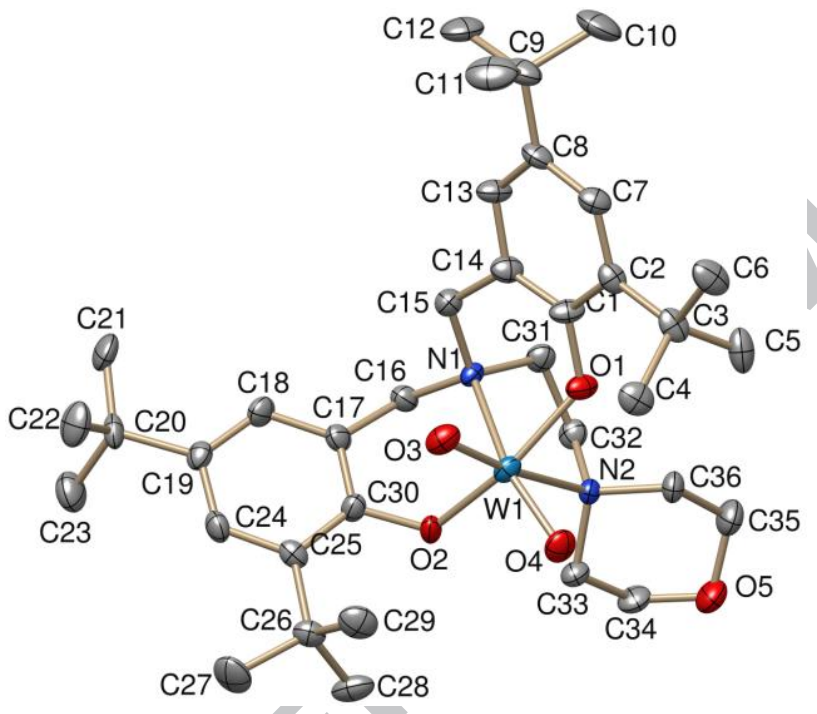

(c)

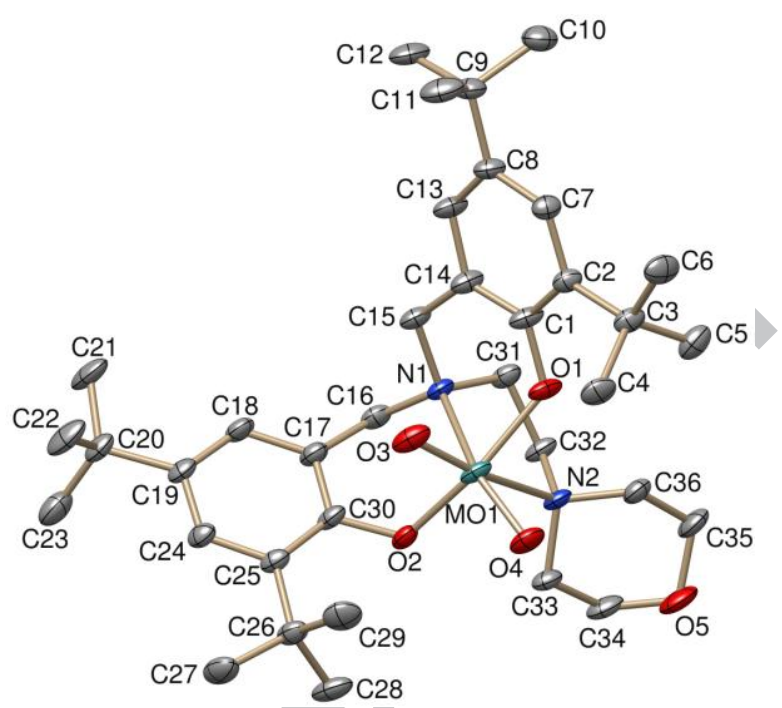

(b)

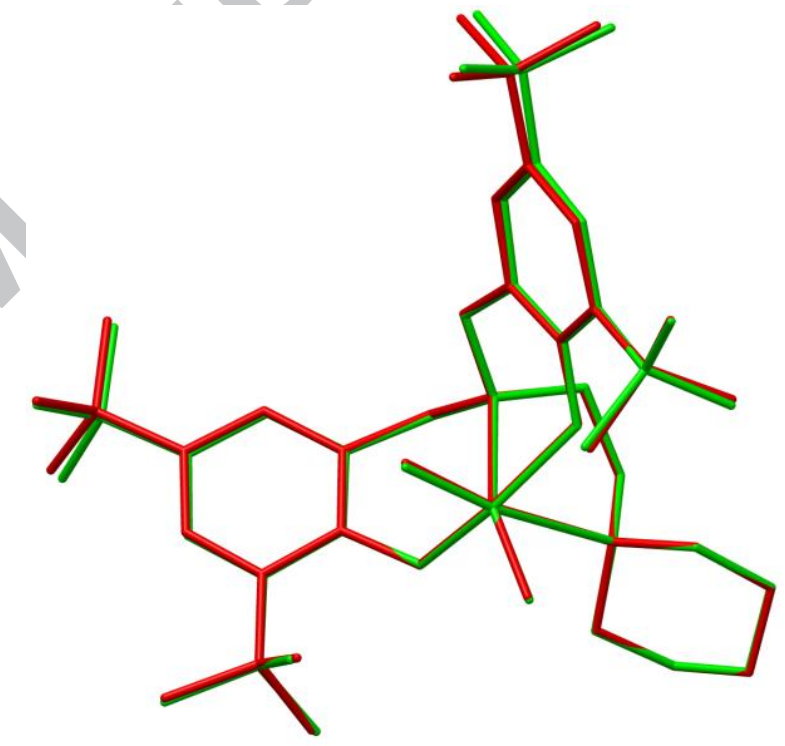

(d)

Figure 2. The solid-state structures of proligand $\mathbf{H}_{2} \mathbf{L}$ (a), complexes $\mathbf{1}$ (b) and $\mathbf{2}$ (c) as well as thesuperimpoed molecular structures of $\mathbf{1}$ (red) and $\mathbf{2}$ (green) (d). For clarity reasons, the C-H hydrogen atoms and the co-crystallized solvent molecules have been omitted. Thermal ellipsoids are drawn at $50 \%$ probability level. 
Table 1. Summary of crystallographic data for $\mathbf{H}_{2} \mathrm{~L}, \mathbf{1}$ and 2

\begin{tabular}{|c|c|c|c|}
\hline & $\mathrm{H}_{2} \mathrm{~L}$ & 1 & 2 \\
\hline $\begin{array}{l}\text { empirical } \\
\text { formula }\end{array}$ & $\mathrm{C}_{36} \mathrm{H}_{58} \mathrm{~N}_{2} \mathrm{O}_{3}$ & $\mathrm{C}_{38} \mathrm{H}_{59} \mathrm{MoN}_{3} \mathrm{O}_{5}$ & $\mathrm{C}_{37} \mathrm{H}_{60} \mathrm{~N}_{2} \mathrm{O}_{6} \mathrm{~W}$ \\
\hline fw & 566.84 & 733.82 & 812.72 \\
\hline temp $(\mathrm{K})$ & $170(2)$ & $120(2)$ & $170(2)$ \\
\hline$\lambda(\AA)$ & 0.71073 & 1.54184 & 0.71073 \\
\hline cryst syst & Triclinic & Monoclinic & Monoclinic \\
\hline space group & $\mathrm{P} \overline{1}$ & $\mathrm{C} 2 / \mathrm{c}$ & $\mathrm{C} 2 / \mathrm{c}$ \\
\hline$a(\AA)$ & $10.6957(2)$ & $27.0047(6)$ & $26.8098(3)$ \\
\hline$b(\AA)$ & $11.4601(2)$ & $11.5353(2)$ & $11.3140(2)$ \\
\hline$c(\AA)$ & $14.7028(3)$ & $26.9948(6)$ & $26.9685(4)$ \\
\hline$\alpha(\operatorname{deg})$ & $90.3150(10)$ & 90 & 90 \\
\hline$\beta(\mathrm{deg})$ & $99.7710(10)$ & 115.291(3) & $113.8780(10)$ \\
\hline$\gamma(\operatorname{deg})$ & $101.8420(10)$ & 90 & 90 \\
\hline$V\left(\AA^{3}\right)$ & $1736.72(6)$ & 7603.1(3) & $7480.1(2)$ \\
\hline $\mathrm{Z}$ & 2 & 8 & 8 \\
\hline$\rho_{\text {calc }}\left(\mathrm{Mg} / \mathrm{m}^{3}\right)$ & 1.084 & 1.282 & 1.443 \\
\hline $\begin{array}{ll}\mu(\mathrm{Mo} & \mathrm{K} \alpha) \\
\left(\mathrm{mm}^{-1}\right) & \end{array}$ & 0.068 & 3.166 & 3.133 \\
\hline No. reflns. & 33698 & 59934 & 50391 \\
\hline Unique reflns. & 10108 & 7991 & 9228 \\
\hline $\operatorname{GOOF}\left(\mathrm{F}^{2}\right)$ & 1.093 & 1.053 & 1.096 \\
\hline $\mathrm{R}_{\text {int }}$ & 0.0418 & 0.0801 & 0.0840 \\
\hline $\mathrm{R} 1^{\mathrm{a}}(I \geq 2 \sigma)$ & 0.0673 & 0.0399 & 0.0588 \\
\hline $\mathrm{wR} 2^{\mathrm{b}}(I \geq 2 \sigma)$ & 0.1500 & 0.1050 & 0.1155 \\
\hline
\end{tabular}

Table 2. Selected bond lengths [ $[\AA]$ and angles $\left[{ }^{\circ}\right]$ for $\mathbf{1}, 2$ and the reported 1.MeOH [27].

$\begin{array}{llll} & \mathbf{1} & \mathbf{2} & \mathbf{1} \cdot \mathbf{M e O H} \\ \text { M1-O1 } & 1.9393(19) & 1.947(4) & 1.938(4) \\ \text { M1-O2 } & 1.9673(18) & 1.921(5) & 1.960(4) \\ \text { M1-O3 } & 1.7062(19) & 1.724(5) & 1.699(4) \\ \text { M1-O4 } & 1.7157(18) & 1.728(5) & 1.699(4) \\ \text { M1-N1 } & 2.3629(19) & 2.373(5) & 2.381(4) \\ \text { M1-N2 } & 2.445(2) & 2.455(5) & 2.466(5) \\ \text { O(1)-M(1)-O(2) } & 156.25(7) & 155.90(19) & 155.73(16) \\ \text { O(3)-M(1)-O(4) } & 108.31(9) & 106.7(2) & 107.6(2) \\ \text { N(1)-M(1)-N(2) } & 73.51(6) & 72.68(17) & 72.98(14) \\ \text { O(1)-M(1)-O(3) } & 95.12(9) & 95.3(2) & 95.2(2) \\ \text { O(1)-M(1)-O(4) } & 98.49(8) & 98.6(2) & 98.76(19)\end{array}$




\subsection{Catalysis studies}

\subsubsection{Catalytic epoxidation}

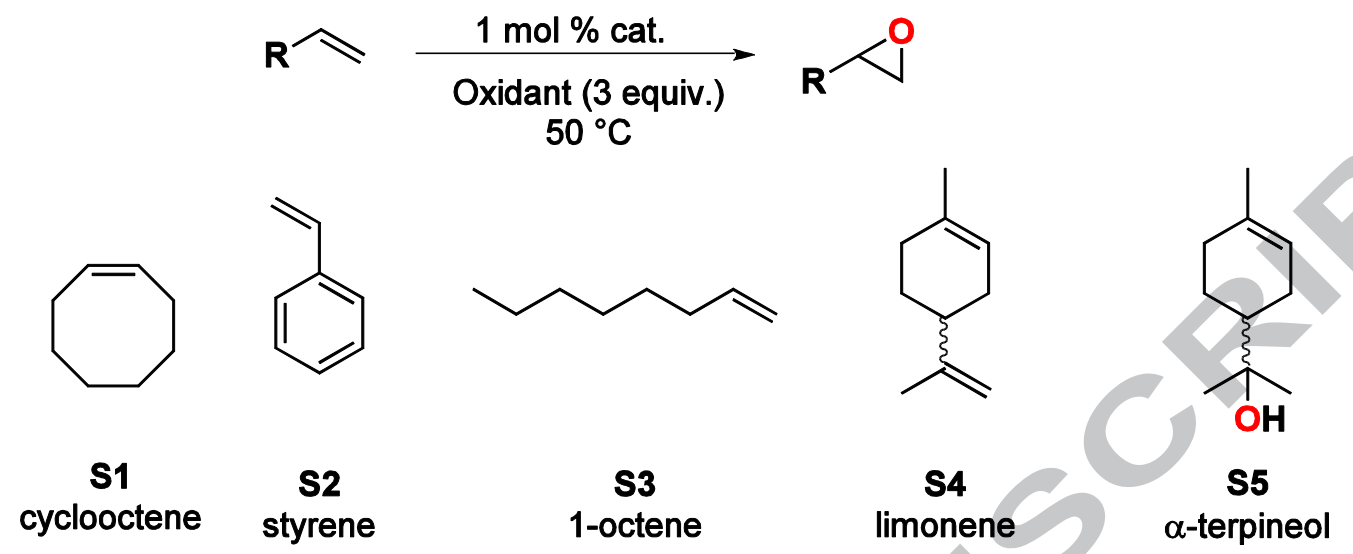

Figure 3. Schematic depiction of catalytic epoxidation of substrates S1-5, using complexes 1 and $\mathbf{2}$ as catalysts.

Catalysts 1 and $\mathbf{2}$ were tested for the epoxidation of five different olefin substrates S1-5 using three equiv. of tert-butyl hydroperoxide $(t \mathrm{BuOOH}, 5.5 \mathrm{M}$ in decane) as oxidant and with 1 mol\% of catalyst in $\mathrm{CHCl}_{3}$ solution at $50{ }^{\circ} \mathrm{C}$. In addition, epoxidation of cis-cyclooctene $\mathbf{S 1}$ was also tested under more green conditions, using hydrogen peroxide $\left(\mathrm{H}_{2} \mathrm{O}_{2}, 30 \%\right)$ as oxidant in $\mathrm{CHCl}_{3}$ and dimethyl carbonate (DMC) as an eco-friendly solvent. Using $\mathrm{H}_{2} \mathrm{O}_{2}$ yields water as the only by-product instead of $t \mathrm{BuOH}$ from $t \mathrm{BuOOH}$, and dimethyl carbonate has proven to be an eco-friendly, non-hazardous substitute for chlorinated organic solvents [39]. Conversions were determined by GC mass spectrometry. The five investigated olefin substrates cis-cyclooctene S1, styrene S2, 1-octene S3, racemic limonene $\mathbf{S 4}$ and racemic $\alpha$ terpineol $\mathbf{S 5}$ are depicted in Figure 3 and results are summarized in Table 3. Whereas complex $\mathbf{1}$ showed catalytic activity with all substrates, the $\mathrm{W}$ analogue $\mathbf{2}$ remained inactive under the same reaction conditions. The lower catalytic epoxidation activity of tungsten complexes relative to their molybdenum analogues has been observed before [9,40-43]. In all cases, blank experiments without catalysts were run.

Complex 1 converts S1 quantitatively to its epoxide with excellent selectivity within $24 \mathrm{~h}$, whereas yields were generally lower for the more challenging substrates S2-5. With S2, low selectivity $(<30 \%)$ to styrene oxide was observed, due to over-oxidation to phenylacetaldehyde and benzaldehyde. In case of $\mathbf{S 3}$, a yield of 1-octene oxide of $28 \%$ with high selectivity (>95\%) after $24 \mathrm{~h}$ was obtained. For limonene S4, low selectivity due to epoxidation of the exocyclic double bond was observed. Finally, for substrate S5, complex 1 showed a similar performance than for S4, but with a low yield (24\%) of epoxide. Since alcohols are known to compete for the vacant coordination site with the substrate, the low conversion for $\mathbf{S 5}$ is most likely caused by the same effect. 
Table 3. Summary of epoxidation results conversion of substrate (selectivity to epoxide) $[\%]^{[\mathrm{a}]}$ ) for complex 1.

\begin{tabular}{c|ccccc}
$\mathbf{1}$ & $\mathbf{S 1}$ & $\mathbf{S 2}$ & $\mathbf{S 3}$ & $\mathbf{S 4}^{[\mathrm{b}]}$ & S5 \\
\hline TBHP, $\mathrm{CHCl}_{3}$ & $>95(>95)$ & $65(27)$ & $28(>95)$ & $>95(32)$ & $81(30)$
\end{tabular}

Conditions: 1 mol\% cat. loading, 3 equiv. oxidant, $50{ }^{\circ} \mathrm{C} ; 2$ showed zero to low $(<10 \%)$ conversions, results are not shown. ${ }^{[a]}$ conversion of substrate (selectivity to epoxide) after $24 \mathrm{~h}$; ${ }^{[\mathrm{b}]}$ sum of cis and trans epoxide is given.

Due to the low activities observed for $\mathbf{S 2 - 5}$, only $\mathbf{S 1}$ was further tested with $\mathrm{H}_{2} \mathrm{O}_{2}$ as oxidant. In order to also test a non-chlorinated solvent, the eco-friendly solvent dimethyl carbonate (DMC) was used instead of $\mathrm{CHCl}_{3}$; the results are summarized in Table 4.

Table 4. Epoxidation results (Yield (selectivity) $[\%]^{[\mathrm{a}]}$ ) with hydrogen peroxide as oxidant.

\begin{tabular}{r|cc} 
S1, $\mathrm{H}_{2} \mathrm{O}_{2}$ & $\mathbf{1}$ & $\mathbf{2}$ \\
\hline $\mathrm{CHCl}_{3}$ & $84(89)$ & $8(81)$ \\
$\mathrm{DMC}$ & $95(>95)$ & $60(>95)$
\end{tabular}

Conditions: 1 mol\% cat. loading, 3 equiv. $\mathrm{H}_{2} \mathrm{O}_{2}, 50{ }^{\circ} \mathrm{C}{ }^{[a]}$ yield of epoxide (selectivity to) after $24 \mathrm{~h}$.

Similar to previous observations with the published complexes 3-6 ( $c f$. Figure 1), tungsten complex 2 is more active in DMC compared to $\mathrm{CHCl}_{3}$ when using $\mathrm{H}_{2} \mathrm{O}_{2}$ as oxidant [10a]. Under otherwise similar conditions, complex 2 is 7.5 times more active in the eco-friendly solvent DMC compared to chlorinated solvent $\mathrm{CHCl}_{3}$. Also the selectivity towards cyclooctene oxide is enhanced in DMC (Table 4). Furthermore, complex 1 showed an increased activity in DMC, reaching essentially full conversion of substrate after already $7 \mathrm{~h}$ (Figure 4).

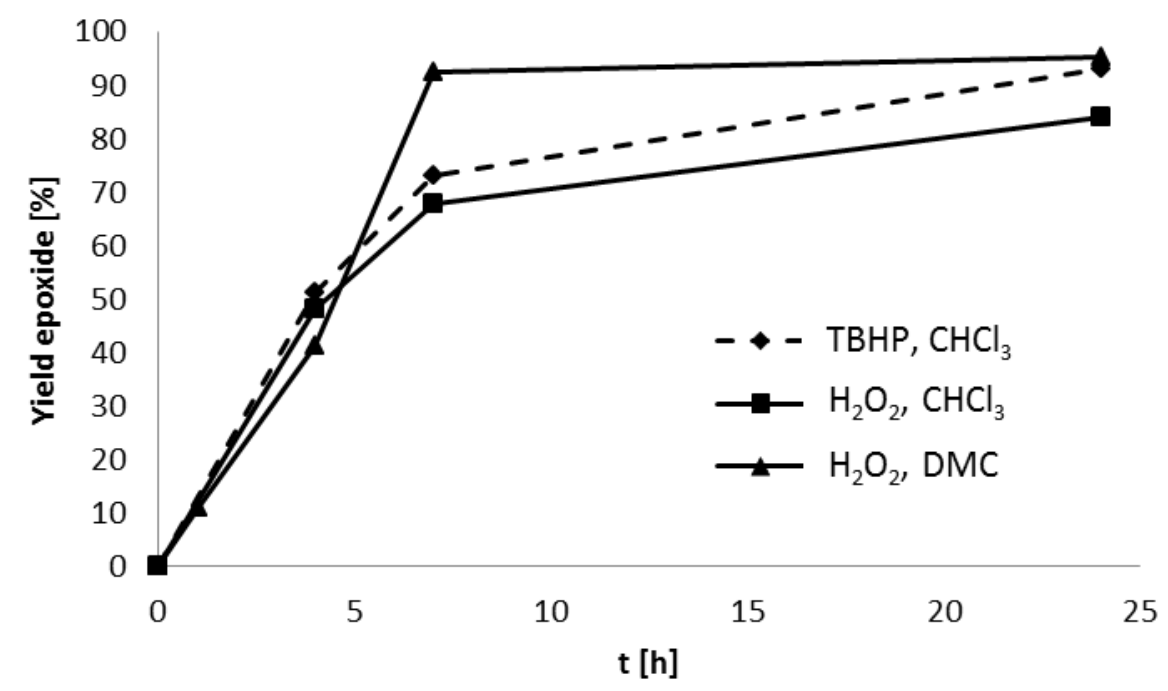

Figure 4. Time-conversion plot of complex $\mathbf{1}$ for epoxidation of $\mathbf{S 1}$ with two different oxidants and solvents $(\mathrm{DMC}=$ dimethyl carbonate $)$. 
The overall lower activity of $\mathrm{W}$ complex $\mathbf{2}$ with $\mathrm{H}_{2} \mathrm{O}_{2}$ as oxidant compared to Mo complex $\mathbf{1}$ is somewhat unexpected. The exact opposite activity was overserved with previously published examples, including complexes 3-6 [10a,40,43-45]. Examples of Mo complexes like $\mathbf{1}$ giving high conversions with $\mathbf{S} 1$ and $\mathrm{H}_{2} \mathrm{O}_{2}$ are scarce in literature [10a,43,46].

\subsubsection{Catalytic sulfoxidation}

Complexes 1-6 were tested as catalysts for sulfoxidation of methyl- $p$-tolyl sulfide with two equivalents of tert-butyl hydroperoxide or aqueous $\mathrm{H}_{2} \mathrm{O}_{2}$ as oxidants (Scheme 1). The reactions were run in $\mathrm{CDCl}_{3}$ or $\mathrm{CD}_{3} \mathrm{CN}$ or $\mathrm{CD}_{3} \mathrm{CD}_{2} \mathrm{OD}$ solutions at $25{ }^{\circ} \mathrm{C}$ while the reaction course was monitored by ${ }^{1} \mathrm{H}$ NMR. In the control experiments, no reactions occurred without any catalyst. All W complexes proved inactive under applied conditions. Conversely, with the Mo complexes the catalytic reactions commenced instantly without any noticeable induction times. The sulfoxidation of methyl-p-tolylsulfide in $\mathrm{CDCl}_{3}$ using $t \mathrm{BuOOH}$ as oxidant was accomplished by all molybdenum complexes with high selectivity and without any sign of the formation of sulfone. Complex 3 exhibited the fastest reaction with a half-life of approximately 5 minutes compared to the other two complexes $\mathbf{1}$ and $\mathbf{5}$, which showed halflives of approximately 15 minutes under similar conditions.

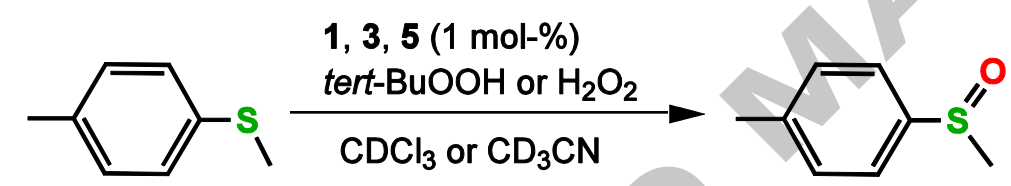

\section{Scheme 1}

Under the experimental conditions used, the sulfoxidation reactions gave good yields (>90\%) while the calculated turnover frequencies (TOFs) for complexes $\mathbf{1}, \mathbf{3}$ and $\mathbf{5}$ were $245 \mathrm{~h}^{-1}, 485$ $\mathrm{h}^{-1}$ and $157 \mathrm{~h}^{-1}$, respectively (Table 5). Importantly, the sulfoxidation was found to be selective, without any sign of the formation of sulfone. The (possible) enantioselectivities of the sulfoxidation reactions were not evaluated.

The molybdenum complexes were also tested as catalysts for sulfoxidation of the same substrate in $\mathrm{MeCN}-\mathrm{d}_{3}$ using hydrogen peroxide as oxidant. All complexes showed almost equal activities (Table 6), and these activities were clearly lower than in the analogous reactions employing $t \mathrm{BuOOH}$ (Table 5). After completion of the reaction, only small amounts of sulfone as a by-product were observed.

The sulfoxidations were run in ethanol- $\mathrm{d}_{6}$ in order to compare different oxidants under identical conditions. All catalysts showed very low epoxidation activities when $t \mathrm{BuOOH}$ was used as an oxidant, but the activities were high with $\mathrm{H}_{2} \mathrm{O}_{2}$ as an oxygen source (see Tables 5 and 6). After completion of the reactions, negligible amounts of sulfone as a by-product were observed when $\mathrm{H}_{2} \mathrm{O}_{2}$ was used. 
Table 5. Catalytic sulfoxidation of methyl-p-tolylsulfide by tert-BuOOH at $25{ }^{\circ} \mathrm{C}$ in $\mathrm{CDCl}_{3}$ and $\mathrm{EtOH}-\mathrm{d}_{6}$.

\begin{tabular}{|c|c|c|c|c|c|c|}
\hline Catalyst & Solvent & Yield $(\%)^{\mathrm{a}}$ & TOF $\left(h^{-1}\right)^{b}$ & Solvent & Yield $(\%)^{\mathrm{c}}$ & TOF $\left(h^{-1}\right)^{b}$ \\
\hline 1 & \multirow[t]{3}{*}{$\mathrm{CDCl}_{3}$} & 92 & 245 & \multirow[t]{3}{*}{$\mathrm{EtOH}-\mathrm{d}_{6}$} & 84 & 12 \\
\hline 3 & & 97 & 485 & & 47 & 0 \\
\hline 5 & & 90 & 157 & & 54 & \\
\hline
\end{tabular}

Reaction conditions: 1 mol-\% of catalyst, 2.0 equivalents of tert-BuOOH. ${ }^{a}$ Yield of the product measured by ${ }^{1} \mathrm{H}$ NMR after an hour. ${ }^{\text {b }}$ TOF calculated after $10 \mathrm{~min}$ of reaction as (mol product) (mol catalyst) $)^{-1}(\mathrm{t} / \mathrm{h})^{-1}$. ${ }^{\mathrm{c}}$ Yield of the product measured by ${ }^{1} \mathrm{H}$ NMR after $24 \mathrm{~h}$.

Table 6. Catalytic sulfoxidation of methyl- $p$-tolylsulfide by $\mathrm{H}_{2} \mathrm{O}_{2}$ at $25{ }^{\circ} \mathrm{C}$ in $\mathrm{MeCN}-\mathrm{d}_{3}$ and ethanol-d $\mathrm{d}_{6}$.

\begin{tabular}{|c|c|c|c|c|c|c|}
\hline Catalyst & Solvent & Yield $(\%)^{\mathrm{a}}$ & TOF $\left(h^{-1}\right)^{b}$ & Solvent & Yield $(\%)^{\mathrm{c}}$ & TOF $\left(h^{-1}\right)^{b}$ \\
\hline 1 & \multirow[t]{3}{*}{$\mathrm{CDCl}_{3}$} & 87 & 32 & \multirow{3}{*}{ EtOH-d 6} & 99 & 78 \\
\hline 3 & & 99 & 49 & & 98 & 120 \\
\hline 5 & & 94 & 43 & & 98 & 114 \\
\hline
\end{tabular}

Reaction conditions: 1 mol- $\%$ of catalysts, 2.0 equivalents of $35 \% \mathrm{H}_{2} \mathrm{O}_{2} \cdot{ }^{\mathrm{a}}$ Yield of the product measured by ${ }^{1} \mathrm{H}$ NMR after three hours. ${ }^{\mathrm{b}} \mathrm{TOF}$ calculated after $60 \mathrm{~min}$ of reaction as (mol product) (mol catalyst $)^{-1}(\mathrm{t} / \mathrm{h})^{-1}$. ${ }^{\mathrm{c}}$ Yield of the product measured by ${ }^{1} \mathrm{H}$ NMR after two hours. ${ }^{\mathrm{d}}$ TOF calculated after $10 \mathrm{~min}$ of reaction as (mol product) (mol catalyst $)^{-1}(\mathrm{t} / \mathrm{h})^{-1}$.

\subsubsection{Catalytic oxidation of benzoin}

The oxo transfer reactivities of complexes 1-6 (10 mol-\% catalyst loadings) were investigated using benzoin as the substrate and deuterated dimethylsulfoxide (DMSO- $\mathrm{d}_{6}$ ) as an oxygen source at $120{ }^{\circ} \mathrm{C}$. Such reactivity of complex 1 has been investigated earlier although under different conditions, i.e. heating benzoin in the presence of an excess of DMSO in acetonitrile at $80{ }^{\circ} \mathrm{C}$ [27]. The reaction mixtures were characterized by ${ }^{1} \mathrm{H}$ and ${ }^{13} \mathrm{C}$ NMR spectroscopy. After 24 hours, benzil was formed in all experiments in nearly quantitative (> 95\%) yields, while no reactions were seen when the complexes were absent. During the reactions, all studied catalysts showed almost the same performance, although molybdenum catalysts are usually reported to show higher oxotransfer activities than their tungsten counterparts [31]. Formation of the co-product dimethyl sulfide (DMS) was detected qualitatively using ${ }^{13} \mathrm{C}$ NMR spectroscopy. In the ${ }^{1} \mathrm{H}$ NMR spectra some unidentified signals were observed after prolonged heating. During the course of the reaction, the $\mathrm{MoO}_{2}(\mathrm{VI})$ and $\mathrm{WO}_{2}(\mathrm{VI})$ complexes are proposed to react with $\mathrm{C}_{6} \mathrm{H}_{5} \mathrm{CH}(\mathrm{OH}) \mathrm{C}(\mathrm{O}) \mathrm{C}_{6} \mathrm{H}_{5}$ and are subsequently converted to $\mathrm{MoO}(\mathrm{IV})$ and $\mathrm{WO}(\mathrm{IV})$ complexes while $\mathrm{C}_{6} \mathrm{H}_{5} \mathrm{C}(\mathrm{O}) \mathrm{C}(\mathrm{O}) \mathrm{C}_{6} \mathrm{H}_{5}$ is formed as another product (Scheme 2) [47].<smiles>O=C(c1ccccc1)C(O)c1ccccc1</smiles>

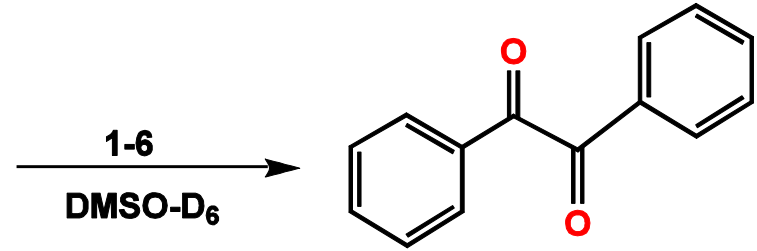




\section{Scheme 2}

A simplified catalytic cycle for the biomimetic oxidation of benzoin with dimethyl sulfoxide (DMSO) to give dimethyl sulfide (DMS) and benzil is shown in Scheme 3. The colour of the reaction mixtures remained yellow throughout the reaction, suggesting that $\mu$-oxido-M(V) $(\mathrm{M}=\mathrm{Mo}, \mathrm{W})$ complexes, which are expected to be of purple colour with relatively high extinction coefficients were not formed.[48] The reduced Mo(IV) complexes are not stable, and are presumably rapidly oxidized to the original compounds to complete the catalytic cycle $[49,50]$.

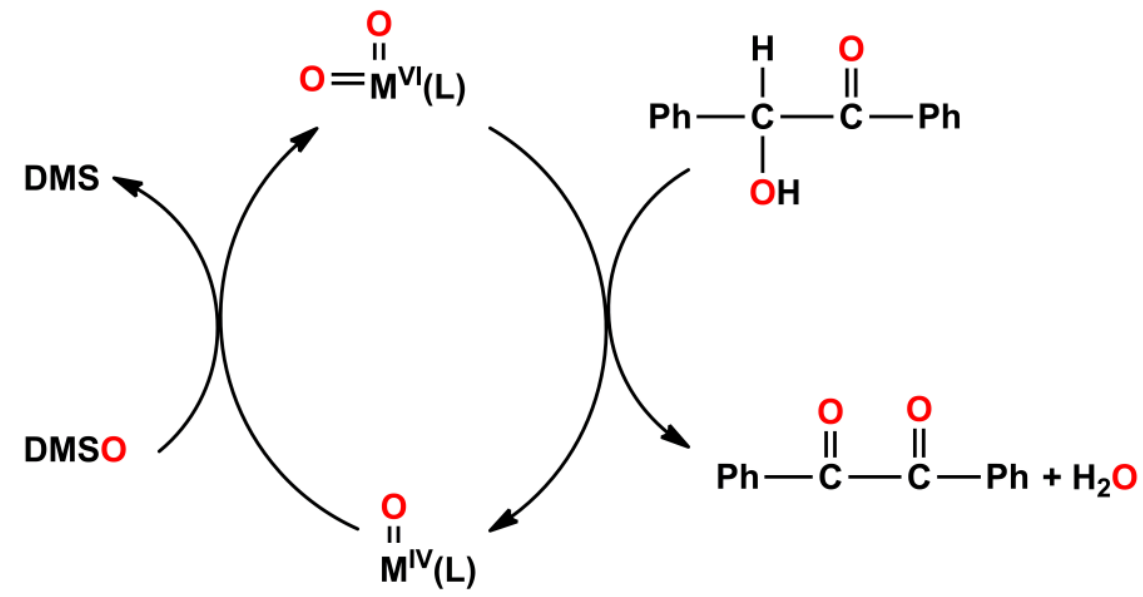

Scheme 3 (adapted from reference 31)

\section{Summary and conclusions}

The new tungsten complex $\left[\mathrm{WO}_{2}(\mathbf{L})\right](2)$ based on the tripodal tetradentate amino bisphenol proligand $\mathbf{H}_{2} \mathbf{L}$ has been synthesized and characterized. Complex $\mathbf{2}$ and its molybdenum analogue $\left[\mathrm{MoO}_{2}(\mathbf{L})\right]$ (1) were examined as catalysts for epoxidation of various alkenes using tert- $\mathrm{BuOOH}$ or $\mathrm{H}_{2} \mathrm{O}_{2}$ as terminal oxidants. The molybdenum complex 1 exhibited higher epoxidation activities than its tungsten analogue, but the latter complex showed markedly improved catalytic activity when the solvent medium was changed from $\mathrm{CHCl}_{3}$ to dimethyl carbonate. These results demonstrate that the use of the morpholine side-arm in complexes $\mathbf{1}$ and 2 yields active, stable epoxidation catalysts. Since the ligand also allows for epoxidations with aqueous $\mathrm{H}_{2} \mathrm{O}_{2}$ in the eco-friendly solvent dimethyl carbonate, a pronounced stability towards $\mathrm{H}_{2} \mathrm{O}$, the side product from $\mathrm{H}_{2} \mathrm{O}_{2}$, is demonstrated. Especially Mo complex $\mathbf{1}$ shows catalytic activity in both the biphasic system $\mathrm{CHCl}_{3} / \mathrm{H}_{2} \mathrm{O}_{2}$ as well as the single-phasic $\mathrm{DMC} / \mathrm{H}_{2} \mathrm{O}_{2}$. This might also point to a certain phase transfer ability of complex $\mathbf{1}$ between the organic phase of the substrate and the aqueous phase of the oxidant.

The six complexes used in the present study are active catalysts for sulfoxidation and oxidation of benzoin. Among them, the three molybdenum complexes proved to be highly selective and effective sulfoxidation catalysts while the analogous tungsten complexes did not show any reactivity under the same conditions. All complexes showed almost similar catalytic activities for oxidation of benzoin to benzil, leading to nearly quantitative (>95\%) yields. The overall lower catalytic activities exhibited by the tungsten complexes may be related to the 
higher bond dissociation energies for tungsten-oxido bonds relative to analogous molybdenum-oxido bonds.

\section{Experimental}

\subsection{General and instrumentation}

Unless otherwise specified, all experiments were run under atmospheric conditions. [W(eg $)_{3}$ ] was prepared by a literature method [51]. The ligand precursors $\mathbf{H}_{2} \mathbf{L}^{\prime}$ and $\mathbf{H}_{2} \mathbf{L}^{\prime \prime}$ were also prepared by published methods [28,52,53], while $\mathbf{H}_{2} \mathbf{L}$ was synthesized by a solvent-free version of a published method [28] (see Supplementary Material). All other chemicals were from commercial sources and were used as received. The ${ }^{1} \mathrm{H}$ and ${ }^{13} \mathrm{C}$ NMR spectra were recorded on a Bruker $300 \mathrm{MHz}$ instrument or a Varian Inova $500 \mathrm{MHz}$ spectrometer using deuterated chloroform as solvent, and referenced to the residual signal of the solvent. The IR spectra were recorded on a Bruker Vertex Optics 70 spectrometer. Infrared bands are reported with wave number $\left(\mathrm{cm}^{-1}\right)$ and intensities $(\mathrm{br}=$ broad, vs $=$ very strong, $\mathrm{s}=$ strong, $\mathrm{m}=$ medium, $w=$ weak). UV-vis measurements were performed on a Varian 300 Bio UV-vis spectrophotometer. Mass spectrometry was performed with a Waters ZQ 4000 spectrometer using CsI as a calibrant. Gas chromatography-mass spectroscopy measurements (GC-MS) were performed with Agilent 7890 A (column type Agilent 19091J-433), coupled to an Agilent 5975 C mass spectrometer. A Heidolph Parallel Synthesizer 1 was used for all epoxidation experiments.

[WO $\left.\mathbf{W}_{2}(\mathbf{L})\right] \cdot \mathbf{M e O H}(\mathbf{2} \cdot \mathbf{M e O H})$. The ligand precursor $\mathbf{H}_{2} \mathbf{L}(0.31 \mathrm{~g}, 0.549 \mathrm{mmol})$ was dissolved in $5 \mathrm{~mL} \mathrm{CHCl}_{3}$ and added to a suspension of $\left[\mathrm{W}(\mathrm{eg})_{3}\right](0.20 \mathrm{~g}, 0.549 \mathrm{mmol})$ in $5 \mathrm{~mL}$ of methanol. The orange mixture was stirred and heated at $70{ }^{\circ} \mathrm{C}$. After $1 \mathrm{~h}$ of stirring, the reaction mixture was allowed to concentrate by slow evaporation at room temperature until white crystals were obtained. Compound 2 was isolated in $62 \%$ yield $(0.28 \mathrm{~g}) .{ }^{1} \mathrm{H}$ NMR (500 $\left.\mathrm{MHz}, \mathrm{CDCl}_{3}\right) \delta 7.35(\mathrm{~d}, J=2.4 \mathrm{~Hz}, 2 \mathrm{H}), 6.98(\mathrm{~d}, J=2.4 \mathrm{~Hz}, 2 \mathrm{H}), 4.34(\mathrm{~s}, 2 \mathrm{H}), 4.27(\mathrm{~d}, J=$ $14.2 \mathrm{~Hz}, 2 \mathrm{H}), 4.08(\mathrm{~d}, J=14.2 \mathrm{~Hz}, 2 \mathrm{H}), 4.01(\mathrm{t}, J=5.8 \mathrm{~Hz}, 2 \mathrm{H}), 3.86-3.78(\mathrm{~m}, 2 \mathrm{H}), 3.51(\mathrm{~s}$, $\left.3 \mathrm{H}, \mathrm{CH}_{3} \mathrm{OH}\right), 3.19(\mathrm{t}, J=5.8 \mathrm{~Hz}, 2 \mathrm{H}), 3.06(\mathrm{t}, J=5.8 \mathrm{~Hz}, 2 \mathrm{H}), 2.92(\mathrm{~d}, J=14.2 \mathrm{~Hz}, 2 \mathrm{H}), 1.48$ $(\mathrm{s}, 18 \mathrm{H}), 1.30(\mathrm{~s}, 18 \mathrm{H}), 1.03\left(\mathrm{~s}, \mathrm{CH}_{3} \mathrm{OH}\right) .{ }^{13} \mathrm{C} \mathrm{NMR}\left(126 \mathrm{MHz}, \mathrm{CDCl}_{3}\right) \delta 159.00,143.19$, 137.48, 124.01, 123.16, 122.50 (Ar-C), 70.73, 62.14, 62.08, 56.18, $53.84\left(\mathrm{CH}_{2}\right), 50.85\left(\mathrm{CH}_{3}\right.$, $\left.\mathrm{CH}_{3} \mathrm{OH}\right), 34.94,34.23\left[\mathrm{C}\left(\mathrm{CH}_{3}\right)_{3}\right], 31.61,30.44\left(\mathrm{CH}_{3}\right)$. Selected FT-IR $\left(\mathrm{cm}^{-1}\right)$ 946s $(\mathrm{W}=\mathrm{O})$, 900s (W=O). UV-vis in $\mathrm{CH}_{3} \mathrm{CN}: \lambda_{\max }, \mathrm{nm}\left(\varepsilon, \mathrm{M}^{-1} \mathrm{~cm}^{-1}\right)$ : 381 (3530). ESI-MS: $m / z=803$ $[2+\mathrm{Na}]^{+}, 781[2+\mathrm{H}]^{+}, 567\left[\mathbf{H}_{2} \mathbf{L}+\mathrm{H}\right]^{+}$.

\subsection{Epoxidation of olefins}

In a typical experiment, $2-3 \mathrm{mg}$ of catalyst $(1 \mathrm{~mol}-\%)$ were dissolved in $\mathrm{CHCl}_{3}(0.5 \mathrm{~mL})$ and mixed with a specific substrate (1 equiv.) and $10 \mu \mathrm{L}$ of mesitylene (internal standard) at 50 ${ }^{\circ} \mathrm{C}$. To start the reaction, 3 equiv. of oxidant, tert-butylhydroperoxide (5.5 $\mathrm{M}$ in decane) and $\mathrm{H}_{2} \mathrm{O}_{2}(50 \%$ in water) were added. Aliquots for GC-MS $(20 \mu \mathrm{L})$ were withdrawn at given time intervals, quenched with $\mathrm{MnO}_{2}$ and diluted with HPLC-grade ethyl acetate. The reaction products were analyzed by GC-MS (Agilent Technologies 7890 GC System), and the epoxide 
produced from each reaction mixture was quantified versus mesitylene as the internal standard.

\subsection{Sulfoxidation reactions}

The experiments were run at room temperature in deuterated chloroform or acetonitrile or ethanol solutions using 1:2 molar ratios of substrate $/ \mathrm{BuOOH}$ or $\mathrm{H}_{2} \mathrm{O}_{2}(0.19 \mathrm{M}: 0.38 \mathrm{M})$ and $10 \mu \mathrm{L}$ of 1,2-dichloroethane added as an internal standard in a $5 \mathrm{~mm}$ NMR tube. The reactions were monitored by ${ }^{1} \mathrm{H}$ NMR spectroscopy at five-minute intervals. The reaction rates were estimated upon the integrated intensities of substrate and product spectra. In the sulfoxidation test, the sulfide methyl singlet at 2.45 was turned to the sulfoxide methyl singlet at $2.71 \mathrm{ppm}$.

\subsection{Catalytic benzoin oxidation}

In a typical test reaction, $0.10 \mathrm{mmol}(21 \mathrm{mg})$ of benzoin and $0.01 \mathrm{mmol}$ of catalyst were dissolved in $1.0 \mathrm{~mL}$ of deuterated dimethyl sulfoxide in a liquid scintillation vial sealed with a screw cap and maintained at $120{ }^{\circ} \mathrm{C}$ for $24 \mathrm{~h}$. The reaction mixture was subsequently allowed to cool to room temperature. An aliquot of the reaction solution was placed in an NMR tube and the substrate conversion was assessed by ${ }^{1} \mathrm{H}$ NMR spectroscopy. The conversion of benzoin to benzil was detected whereas the yield was over $95 \%$ in all experiments.

\subsection{X-ray structure determination}

The crystals of $\mathbf{1}, \mathbf{2}$, and $\mathbf{H}_{\mathbf{2}} \mathbf{L}$ were immersed in cryo-oil, mounted in a MiTeGen loop, and measured at a temperature of 120 or $170 \mathrm{~K}$. The X-ray diffraction data were collected on a Rigaku Oxford Diffraction Supernova diffractometer or on a Bruker KappaApex II using $\mathrm{Cu}$ $\mathrm{K} \alpha$ radiation $(\lambda=1.54184 \AA)$ or Mo $\mathrm{K} \alpha(\lambda=0.71073 \AA)$ radiation. The CrysAlisPro [54] or Denzo/Scalepack [55] program packages were used for cell refinements and data reductions. A multi-scan or numerical absorption correction was applied to all data (SADABS, [56] CrysAlisPro [54]). The structures were solved by charge flipping method using the Superflip [57] program. Structural refinements were carried out using SHELXL [58] program with the Olex2 [59] and SHELXLE [60] graphical user interfaces. Structure 2 was refined as a twinned crystal (twin matrix $0010-100100$ ). The BASF value was refined to 0.14 . Hydrogen atoms were positioned geometrically and constrained to ride on their parent atoms, with $\mathrm{C}-\mathrm{H}=0.95$ $0.99 \AA, \mathrm{O}-\mathrm{H}=0.84 \AA$, and $\mathrm{U}_{\mathrm{iso}}=1.2-1.5 \mathrm{U}_{\text {eq }}$ (parent atom).

\section{Acknowledgements}

This work has been carried out within the framework of COST Action CM1003 Biological oxidation reactions - mechanisms and design of new catalysts. M.K.H thanks the European Commission for an Erasmus Mundus predoctoral fellowship.

\section{Appendix A. Supplementary data}

CCDC 1523698-1523700 contains the supplementary crystallographic data for $\mathbf{H}_{\mathbf{2}} \mathbf{L}, \mathbf{1}$ and $\mathbf{2}$. These data can be obtained free of charge via http://www.ccdc.cam.ac.uk/conts/retrieving.html, or from the Cambridge Crystallographic Data Centre, 12 Union Road, Cambridge CB2 1EZ, UK; fax: (+44) 1223-336-033; or e-mail: deposit@ccdc.cam.ac.uk. 


\section{References}

[1] A.W. Kleij, Eur. J. Inorg. Chem. (2009) 193.

[2] G. Licini, M. Mba, C. Zonta, Dalton Trans. (2009) 5265.

[3] K.C. Gupta, A.K. Sutar, Coord. Chem. Rev. 252 (2008) 1420.

[4] N.S. Venkataramanan, G. Kuppuraj, S. Rajagopal, Coord. Chem. Rev. 249 (2005) 1249.

[5] J.A. Schachner, P. Traar, C. Sala, M. Melcher, B.N. Harum, A.F. Sax, M. Volpe, F. Belaj, N.C. Mösch-Zanetti, Inorg. Chem. 51 (2012) 7642.

[6] A. Riisiö, A. Lehtonen, M.M. Hänninen, R. Sillanpää, Eur. J. Inorg. Chem. (2013) 1499.

[7] X. Ma, C. Schulzke, Inorg. Chim. Acta 395 (2013) 218.

[8] T. Heikkilä, R. Sillanpää, A. Lehtonen, J. Coord. Chem. 67 (2014) 1863.

[9] M.E. Judmaier, C.H. Sala, F. Belaj, M. Volpe, N.C. Mösch-Zanetti, New J. Chem. 37 (2013) 2139.

[10] (a) A. Dupé, M.K. Hossain, J.A. Schachner, F. Belaj, A. Lehtonen, E. Nordlander, N.C. Mösch-Zanetti, Eur. J. Inorg. Chem. (2015) 3572. (b) A. Peuronen, A. Lehtonen, Top Catal 59 (2016)1132. (c) W. Wanga, J.-C. Darana, R. Polia, D. Agustin, J. Mol. Catal. A, 416 (2016) 117. (d) S. Ghosh, S.K. Kurapati, S. Pal, Polyhedron 125 (2016) 26. (e) V. Vrdoljak, J. Pisk, B. Prugovečki, D. Agustin, P. Novaka, D. Matković-Čalogović, RSC Adv. 6 (2016) 36384.

[11] O. Wichmann, R. Sillanpää, A. Lehtonen, Coord. Chem. Rev. 256 (2012) 371.

[12] M. Merkel, F.K. Müller, B. Krebs, Inorg. Chim. Acta 337 (2002) 308.

[13] M. Velusamy, M. Palaniandayar, R.S. Gopalan, G.U. Kulkarni, Inorg. Chem. 42 (2003) 8283.

[14] D.C. Crans, J.J. Smee, E. Gaidamauskas, L. Yang, Chem. Rev. 104 (2004) 849.

[15] C. Bolm, Coord. Chem. Rev. 237 (2003) 245.

[16] D. Rehder, C. Schulzke, H. Dau, C. Meinke, J. Hanss, M. Epple, J. Inorg. Biochem. 80 (2000) 115.

[17] M. Mba, M. Pontini, S. Lovat, C. Zonta, G. Bernardinelli, P.E. Kündig, G. Licini, Inorg. Chem. 47 (2008) 8616.

[18] C.R. Cornman, G.J. Colpas, J.D. Hoeschele, J. Kampf, V.L. Pecoraro, J. Am. Chem. Soc. 114 (1992) 9925.

[19] M.M. Whittaker, W.R. Duncan, J.W. Whittaker, Inorg. Chem. 35 (1996) 382.

[20] M. Taki, H. Kumei, S. Nagatomo, T. Kitagawa, S. Itoh, S. Fukuzumi, Inorg. Chim. Acta 300-302 (2000) 622.

[21] Y. Shimazaki, S. Huth, S. Hirota, O. Yamauchi, Inorg. Chim. Acta 331 (2002) 168.

[22] A. Philibert, F. Thomas, C. Philouze, S. Hamman, E. Saint-Aman, J.-L. Pierre, Chem. A Eur. J. 9 (2003) 3803.

[23] A. John, M.M. Shaikh, P. Ghosh, Dalton Trans. (2008) 2815.

[24] Y.-L. Wong, L.H. Tong, J.R. Dilworth, D.K.P. Ng, H.K. Lee, Dalton Trans. 39 (2010) 4602.

[25] J. Hakala, R. Sillanpää, A. Lehtonen, Inorg. Chem. Commun. 21 (2012) 21. 
[26] F. Romano, A. Linden, M. Mba, C. Zonta, G. Licini, Adv. Synth. Catal. 352 (2010) 2937.

[27] M.R. Maurya, B. Uprety, F. Avecilla, Eur. J. Inorg. Chem. (2016) 4802.

[28] A. Riisio, O. Wichmann, R. Sillanpaa, Lett. Org. Chem. 7 (2010) 298.

[29] Y.-L. Wong, Y. Yan, E.S.H. Chan, Q. Yang, T.C.W. Mak, D.K.P. Ng, J. Chem. Soc., Dalton Trans. 2 (1998) 3057.

[30] R. Dinda, P. Sengupta, S. Ghosh, W.S. Sheldrick, Eur. J. Inorg. Chem. (2003) 363.

[31] Y.-L. Wong, J.-F. Ma, W.-F. Law, Y. Yan, W.T. Wong, Z.-Y. Zhang, T.C.W. Mak, D.K.P. Ng, Eur. J. Inorg. Chem. (1999) 313.

[32] M. Huang, C.W. DeKock, Inorg. Chem. 32 (1993) 2287.

[33] W.A. Herrmann, J.J. Haider, J. Rg Fridgen, G.M. Lobmaier, M. Spiegler, J. Organomet. Chem. 603 (2000) 69.

[34] H. Elias, F. Stock, C. Röhr, Acta Cryst. C53 (1997) 862.

[35] P. Subramarian, J.T. Spence, R. Ortega, J.H. Enemark, Inorg. Chem. 23 (1984) 2564.

[36] C.J. Hinshaw, G. Peng, R. Singh, J.T. Spence, J.H. Enemark, M. Bruck, J. Kristofzski, S. L. Merbs, R.B. Ortega, P.A. Wexler, Inorg. Chem. 28 (1989) 4483.

[37] N. Kanehisa, Y. Kai, N. Kasai, H. Yasuda, Y. Nakayama, A. Nakamura, Bull. Chem. Soc. Jpn. 65 (1992) 1197.

[38] B.D. Steffey, P.E. Fanwick, I.P. Rothwell, Polyhedron 9 (1990) 963.

[39] P.Tundo, M. Selva, Acc. Chem. Res. 35 (2002) 706.

[40] A. Jimtaisong, R.L. Luck, Inorg. Chem. 45 (2006) 10391.

[41] F.E. Kühn, W.-M. Xue, A.M. Al-Ajlouni, A.M. Santos, S. Zang, C. C. Romão, G. Eickerling, E. Herdtweck, Inorg. Chem. 41 (2002) 4468.

[42] J. Zhao, A.M. Santos, E. Herdtweck, F.E. Kühn, J. Mol. Catal. A Chem. 222 (2004) 265.

[43] P. Sözen-Aktaş, E. Manoury, F. Demirhan, R. Poli, Eur. J. Inorg. Chem. (2013) 2728.

[44] L. Salles, C. Aubry, R. Thouvenot, F. Robert, C. Doremieux-Morin, G. Chottard, H. Ledon, Y. Jeannin, J.M. Brégeault, Inorg. Chem. 33 (1994) 871.

[45] C. Dinoi, M. Ciclosi, E. Manoury, L. Maron, L. Perrin, R. Poli, Chem. A Eur. J. 16 (2010) 9572.

[46] S.L. Pandhare, R.R. Jadhao, V.G. Puranik, P.V Joshi, E. Capet, M.K. Dongare, S.B. Umbarkar, C. Michon, F. Agbossou-Niedercorn, J. Organomet. Chem. 772-773 (2014) 271.

[47] A. Lehtonen, M. Wasberg, R. Sillanpää, Polyhedron 25 (2006) 767.

[48] A. Thapper, A. Behrens, J. Fryxelius, M.H. Johansson, F. Prestopino, M. Czaun, D. Rehder, E. Nordlander, Dalton Trans. (2005) 3566.

[49] R. Mayilmurugan, B.N. Harum, M. Volpe, A.F. Sax, M. Palaniandavar, N.C. MöschZanetti, Chem. A Eur. J. 17 (2011) 704.

[50] C.J. Doonan, D.A. Slizys, C.G. Young, J. Am. Chem. Soc. 121 (1999) 6430.

[51] F.A. Schröder, J. Scherle, Z. Naturforsch. 28b (1973) 46.

[52] E. Safaei, M. Rasouli, T. Weyhermüller, E. Bill, Inorg. Chim. Acta 375 (2011) 158.

[53] J. Weil, R.T. Mathers, Getzler, D.Y.L. Yutan, Macromolecules 45 (2012) 1118.

[54] Agilent, CrysAlisPro Software System, Agil. Technol. Inc. Oxfordshire, England, 44 
(2014).

[55] Z. Otwinowski, W. Minor, C.W. Carter, R.M. Sweet, Methods in Enzymol 276 (1997), 307.

[56] G.M. Sheldrick, SADABS, Bruker Nonius scaling and absorption correction -, Bruker AXS, Inc.: Madison, Wisconsin, USA, 2012.

[57] L. Palatinus, G. Chapuis, J. Appl. Crystallogr. 40 (2007) 786.

[58] G.M. Sheldrick, Acta Cryst. C71 (2015) 3.

[59] O.V. Dolomanov, L.J. Bourhis, R.J. Gildea, J.A.K. Howard, H. Puschmann, J. Appl. Crystallogr. 42 (2009) 339.

[60] C.B. Hübschle, G.M. Sheldrick, B. Dittrich, J. Appl. Cryst. 44 (2011) 1281. 


\section{Graphical Abstract}

$\mathrm{MO}_{2}(\mathrm{M}=\mathrm{Mo}, \mathrm{W})$ of three tripodal amino bisphenolate ligands have been investigated as catalysts in oxotransfer reactions (epoxidation, sulfoxidation, benzoin oxidation). The molybdenum complexes were found to be more active than their tungsten congeners, and are good sulfoxidation catalysts. Complexes exhibited higher activity in dimethyl carbonate (DMC) solvent than in $\mathrm{CHCl}_{3}$.

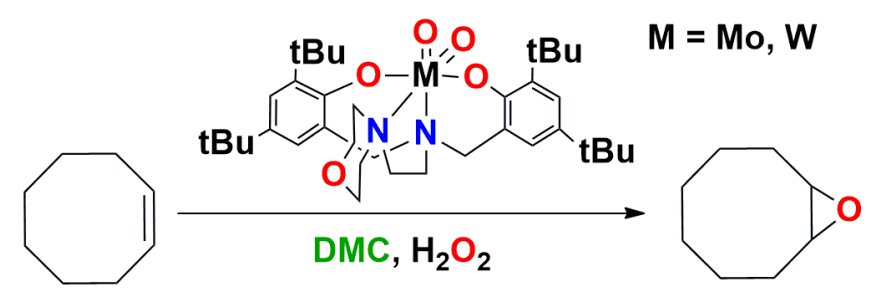

